RESOURCE EXCHANGE

\title{
THAI TRANSIT CAMP NEEDS INFORMATION ON EMPLOYMENT IN CANADA
}

\section{by E. Anne Saunders, Mennonite Central Committee (Bangkok)}

In the Refugee Transit Camp at Panat Nikom, 80 kilometres east of Bangkok. Thailand, refugees bound for Canada may wait anywhere from a month to a year, usually with very little to do with their time. The Mennonite Central Committee has used that time to provide cultural orientation to life in Canada. This project is one of several comprising the Refugee Assistance Programme supported by the Mennonite Central Committee,

MCC (Bangkok) is now trying to incorporate a vocational guidance component into this orientation. It is hoped that through this programme, refugee adults will become aware of their responsibility in finding employment in Canada, and that exposure to information while in the refugee camp will prepare them better for this aspect of their resettlement.

Discussions about refugee employment orientation programmes have been held with the other refugee relief organizations involved in cultural orientation programmes. The Office of the United Nations High Commissioner for Refugees (UNHCR) has expressed a great deal of interest and encouragement in programme expansion in this direction.

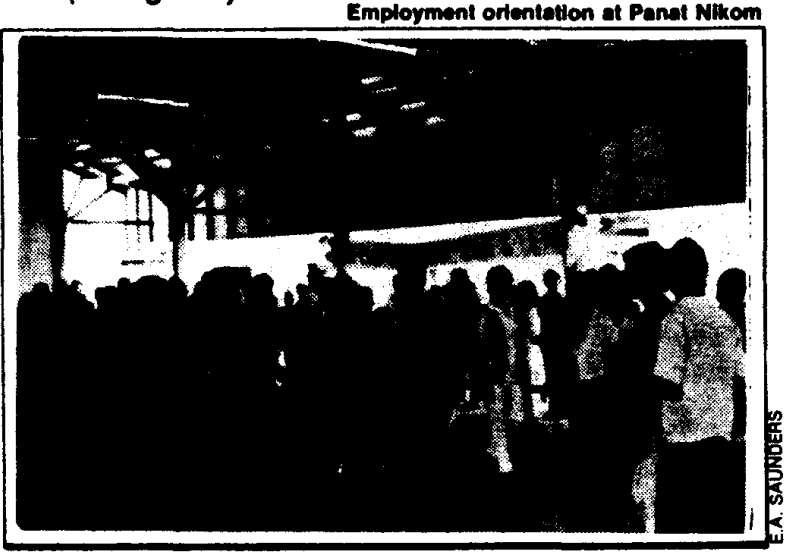

The Canadian Embassy in Bangkok is also supportive of this programme and has given MCC access to their written, pictorial and audio-visual information. However, much of it is naturally geared towards the tourist, businessman or well-informed and well-educated immigrant.

Refugee workers from various agencies cooperate in their efforts to prepare the refugees for their resettlement countries. While there is a shortage of manpower and resource materials, audio-visual equipment is accessible and interpreters are readily available to help get information across to the people. There is also a very well-used library in the camp. Right now there is a small section for Canada. MCC (Bangkok) would like to see this expanded and would like to set up another section entitled "Employment".

In order to get this vocational guidance programme off the ground, MCC (Bangkok) needs written, pictorial and audio-visual materials; its needs information - general statistics and individual stories about the types of jobs that refugees have found; it needs advice as to what sort of employment information should be emphasized. Much of the resettlement information that has been used with refugees in Canada would also be valuable in the Transit Camp. If you or your organization can share this kind of information, please send it at your earliest convenience and by airmail to:

$$
\begin{aligned}
& \text { MCC (Bangkok) } \\
& 5 \text { Convent Road } \\
& \text { Apartment } 19 \\
& \text { Bangkok 5, Thailand }
\end{aligned}
$$

It is hoped that this vocational guidance programme will make resettlement in Canada a less stressful process - for the refugee, the sponsor, the employment counsellor and the employer. 